\title{
Short Note: Seed Source Variation in Seedling and Nodulation Characters in Dalbergia sissoo Roxb.
}

\author{
By G. M. Devagiri ${ }^{1), *)}$, R. C. Dhiman ${ }^{2)}$, P. Naveen Kumar ${ }^{3)}$ and C. S. P. Patil ${ }^{3)}$
}

(Received $12^{\text {th }}$ January 2004)

\begin{abstract}
Study was conducted involving 20 seed sources of Dalbergia sissoo Roxb., collected from the greater part of its distributional range to understand the variation, particularly in nodulation pattern associated with seed sources. Seedling height, number of nodules per seedling and seedling biomass exhibited strong seed source dependent variation. While collar diameter and nodule diameter showed statistically non-significant differences among seed sources. Significant positive correlations were observed between growth characters (seedling height, collar diameter and root length). Highly significant positive correlation was observed between total number of nodules/seedling with root length and seedling dry matter indicating the influence of root length on nodulation and in turn the effect of nodulation on seedling biomass production. The selection therefore, should be aimed at seed source with highest level of susceptibility to root nodulation with rhizobia which could perform well in the initial stages of plantation establishment on poor sites.
\end{abstract}

Key words: Dalbergia sissoo, Seed source, Nodulation, Variability, Selection.

\section{Introduction}

Dalbergia sissoo Roxb., an important multipurpose tree species known for its variety of adaptive and economic traits and being commercially exploited for very hard, strong and durable timber. Natural forests of $D$. sissoo are common in sub-Himalayan tract either pure or in mixtures with Shorea robusta, Acacia catechu, Terminalia tomentosa etc. (CHAMPION and SETH, 1968). D. sissoo being important member of leguminosae, its ability to fix atmospheric $\mathrm{N}_{2}$ enables it to accumulate considerable amount of nitrogen rich biomass which decomposes quickly and improves the organic matter and nutrient status of the soil. It exhibits considerable variation in form and growth characters in its natural range. Most of this variation seems to be a function of edaphic, altitudinal and associated climatic factors in the region.

Inter-specific difference in nodulation of host plants is well documented (MIETTINEN et al., 1992; PoKHRIYAL et al., 1993). Relatively less information is available on intra-specific variation in root nodule formation in tree

\footnotetext{
1) College of Forestry, University of Agricultural Science, Bangalore, Ponnampet-571 216, South Kodagu, Karnataka, India.

2) State Forest Department, Shimla, Himachal Pradesh, India.

3) College of Forestry, University of Agricultural Science, Bangalore, Ponnampet-571 216, South Kodagu, Karnataka, India.

*) Corresponding author: G. M. DevagIRI.

Email: gdevagiri@gmail.com g_devagiri@yahoo.co.in
}

species. This necessitates screening for improved seed sources/host plants having increased symbiotic response. However, DevaGiRI et al. (2001) have reported seed source dependent variation in mycorrhizal colonization and nutrient uptake in $D$. sissoo. The present study aimed at assessing seed source dependent variation in nodulation.

\section{Material and Methods}

Seed material was obtained from collections made for the national level provenance trial of $D$. sissoo co-ordinated by FRI, Dehradun. Out of the total collections made, twenty seed sources representing the species distributional range, with a considerable geographic isolation (latitude, longitude, altitude, climatic factors and soil types) between each seed source, were selected for the present study (Table 1). Seeds of different sources were sown in lines in a specially designed polythene chamber at forest nursery, Forest Research Institute, Dehradun, India. Each seed source was replicated in three lines in Randomised Complete Block Design (RCBD) and final observations were recorded six months after sowing.

Ten randomly selected seedlings in each replication for each seed source were used to measure seedling parameters. Number of green nodules, black nodules

Table 1. - Characteristics of Dalbergia sissoo seed sources.

\begin{tabular}{cllcc}
\hline Code & Seed source & State & $\begin{array}{c}\text { Latitude } \\
\left({ }^{\circ} \mathbf{N}\right)\end{array}$ & $\begin{array}{c}\text { Longitude } \\
\left.\mathbf{(}^{\circ} \mathbf{E}\right)\end{array}$ \\
\hline S1 & Shajanwa & Uttar Pradesh (U.P) & 27.00 & 81.10 \\
S2 & Jahankhelan & Punjab & 31.00 & 75.00 \\
S3 & Kanpur & U.P & 26.28 & 80.24 \\
S4 & Baharaich & U.P & 27.30 & 81.30 \\
S5 & Sahajanpur & U.P & 27.50 & 80.40 \\
S6 & Hissar & Haryana & 29.50 & 75.40 \\
S7 & Hoshiyarpur & Punjab & 31.30 & 76.30 \\
S8 & Muradabad & U.P & 28.50 & 78.50 \\
S9 & Tilyar Zoo & Haryana & 29.00 & 76.10 \\
S10 & Rhotak & Haryana & 28.54 & 76.38 \\
S11 & Etawah & U.P & 26.47 & 79.02 \\
S12 & Simblewala & Nepal & 27.30 & 84.46 \\
S13 & Koshitappu & Nepal & 28.30 & 83.10 \\
S14 & Jaunpur & U.P & 25.46 & 82.44 \\
S15 & Jorhat & Assam & 26.46 & 94.16 \\
S16 & Sontinursery & Haryana & 28.30 & 76.40 \\
S17 & Farinda & Punjab & 30.50 & 73.90 \\
S18 & Tulsipur Gonda & U.P & 27.05 & 82.03 \\
S19 & Pratapgarh & U.P & 25.34 & 81.59 \\
S20 & Pillibhit & U.P & 28.38 & 79.51 \\
\hline & & & &
\end{tabular}


Table 2. - Mean performance of seed source of D. sissoo in seedling and nodulation parameters.

\begin{tabular}{|c|c|c|c|c|c|c|c|c|c|c|}
\hline Code & Seed source & $\begin{array}{c}\text { Seedling } \\
\text { height } \\
(\mathrm{cm})\end{array}$ & $\begin{array}{c}\text { Collar } \\
\text { diameter } \\
(\mathrm{mm})\end{array}$ & $\begin{array}{c}\text { Root } \\
\text { length } \\
\text { (cm) }\end{array}$ & $\begin{array}{c}\text { No. of } \\
\text { green } \\
\text { nodules/ } \\
\text { seedling }\end{array}$ & $\begin{array}{c}\text { No. of } \\
\text { black } \\
\text { nodules/ } \\
\text { seedling }\end{array}$ & $\begin{array}{c}\text { Total } \\
\text { no. of } \\
\text { nodules/ } \\
\text { seedling }\end{array}$ & $\begin{array}{c}\text { Nodule } \\
\text { diameter } \\
(\mathrm{mm})\end{array}$ & $\begin{array}{l}\text { Seedling } \\
\text { fresh } \\
\text { weight } \\
\text { (g) }\end{array}$ & $\begin{array}{c}\text { Seedling } \\
\text { dry } \\
\text { weight } \\
\text { (g) }\end{array}$ \\
\hline $\mathrm{S} 1$ & Shajanwa & 13.80 & 1.51 & 13.48 & 4.52 & 2.77 & 7.29 & 1.27 & 1.40 & 0.92 \\
\hline $\mathrm{S} 2$ & Jahankhelan & 7.60 & 0.83 & 8.08 & 2.67 & 2.62 & 5.25 & 1.13 & 0.41 & 0.25 \\
\hline $\mathrm{S} 3$ & Kanpur & 7.24 & 0.96 & 9.51 & 3.33 & 2.17 & 4.67 & 1.09 & 0.43 & 0.26 \\
\hline $\mathrm{S} 4$ & Baharaich & 9.51 & 1.06 & 12.15 & 8.33 & 2.67 & 11.55 & 1.19 & 0.85 & 0.66 \\
\hline S5 & Sahajanpur & 7.86 & 0.78 & 10.94 & 3.11 & 8.00 & 11.11 & 1.00 & 0.39 & 0.27 \\
\hline S6 & Hissar & 10.02 & 1.06 & 7.83 & 0.63 & 0.51 & 1.13 & 1.10 & 0.38 & 0.23 \\
\hline S7 & Hoshiyarpur & 8.53 & 0.95 & 11.83 & 4.00 & 4.67 & 7.00 & 1.13 & 0.44 & 0.36 \\
\hline $\mathrm{S} 8$ & Muradabad & 8.35 & 0.91 & 11.18 & 1.77 & 2.00 & 3.57 & 1.38 & 0.46 & 0.25 \\
\hline S9 & Tilyar Zoo & 6.63 & 0.93 & 11.78 & 2.00 & 4.67 & 6.33 & 1.01 & 0.48 & 0.37 \\
\hline $\mathrm{S} 10$ & Rhotak & 8.34 & 1.11 & 14.44 & 5.00 & 4.13 & 9.11 & 1.11 & 0.72 & 0.61 \\
\hline $\mathrm{S} 11$ & Etawah & 8.68 & 0.99 & 8.37 & 2.89 & 3.89 & 6.78 & 1.30 & 0.68 & 0.57 \\
\hline $\mathrm{S} 12$ & Simblewala & 8.15 & 1.13 & 13.63 & 4.67 & 6.78 & 11.11 & 1.24 & 0.56 & 0.42 \\
\hline $\mathrm{S} 13$ & Koshitappu & 10.17 & 1.09 & 12.23 & 5.33 & 8.00 & 13.33 & 1.15 & 0.56 & 0.40 \\
\hline $\mathrm{S} 14$ & Jaunpur & 8.33 & 0.82 & 11.60 & 3.33 & 3.67 & 7.00 & 0.86 & 0.46 & 0.38 \\
\hline $\mathrm{S} 15$ & Jorhat & 6.76 & 0.82 & 10.30 & 2.33 & 2.00 & 4.33 & 1.06 & 0.45 & 0.29 \\
\hline S16 & Sontinursery & 9.05 & 1.02 & 11.60 & 2.33 & 2.67 & 5.00 & 1.39 & 0.38 & 0.25 \\
\hline $\mathrm{S} 17$ & Farinda & 6.64 & 1.27 & 8.51 & 2.54 & 2.00 & 4.54 & 0.98 & 0.28 & 0.18 \\
\hline $\mathrm{S} 18$ & Tulsipur Gonda & 13.59 & 1.40 & 16.03 & 3.55 & 5.11 & 8.67 & 1.19 & 0.91 & 0.83 \\
\hline $\mathrm{S} 19$ & Pratapgarh & 9.72 & 1.53 & 21.03 & 7.11 & 7.78 & 14.89 & 1.98 & 1.11 & 0.89 \\
\hline \multirow[t]{3}{*}{$\mathrm{S} 20$} & Pillibhit & 9.72 & 0.72 & 15.30 & 5.56 & 5.22 & 10.11 & 1.04 & 0.45 & 0.37 \\
\hline & C.D.@ $5 \%$ & 1.66 & NS & 2.48 & 1.75 & 1.93 & 2.72 & NS & 0.51 & 0.23 \\
\hline & Mean & 8.95 & 1.04 & 11.99 & 3.75 & 4.07 & 7.64 & 1.18 & 0.59 & 0.44 \\
\hline
\end{tabular}

NS: Non-significant.

and total number of nodules on intact root system of each seedling were counted and also the size of the nodule was recorded. Total seedling dry matter was measured after drying the root, shoot and leaf for $24 \mathrm{~h}$ at $60^{\circ} \mathrm{C}$. Data were subjected to analysis of variance using statistical model: $Y_{1}=T R T * R$ (Error). Least significant differences were calculated and seed sources were compared based on variable values. Simple correlations (r) among different traits were calculated as described by SNEDECOR and COCHRAN (1967).

\section{Results}

\section{Growth performance}

Analysis of variance obtained on seedling and nodulation characters showed significant differences in growth and nodulation characters among seed sources except seedling collar and nodule diameter (Table 2). The highest range of seed sources means was recorded for number of green nodules per seedling; 0.63-8.33 (S6 and S4); number of black nodules per seedling; 0.51-8.00 (S6 and S5, S13); total number of nodules per seedling; 1.13-14.89 (S6 and S19); root length; 7.83-21.03 cm (S6 and S19); seedling fresh weight; $0.28-1.40 \mathrm{~g}$ (S17 and S1) and dry weight; 0.18-0.92 g (S17 and S17). Among the seed sources studied, the performance of S10, S13 and S20 seed sources of Haryana, Nepal and U.P respec- tively, was comparatively better than other seed sources. Poor height growth was observed in seedlings of Tilyar Zoo (S9), Farinda (S17) and Jorhat (S15) and they were statistically on par with Jahankhelan (S2) and Kanpur (S3) but significantly different from others.

Seedlings of Pratapgarh (S19), Koshitappu (S13) and Baharaich (S4) seed sources developed significantly more number of nodules per seedling in comparison to others however, S19 differed significantly from S13 and S4. Although Shajanwa (S1) seed source had good height and more biomass, yet they developed less number (7.29) of nodules per seedling. Lesser nodule formation was observed in seedlings of Hissar (S6), followed by Muradabad (S8). These two seed sources formed separate group w.r.t. total number of nodules per seedling.

Seedling fresh and dry weight differed significantly between the seed sources. Shajanwa (S1) seed source though produced fewer nodules per seedling yet had maximum fresh and dry matter yield, followed by Pratapgarh (S19) and Tulsipur Gonda (S18) seed sources. Seedling dry matter production in $\mathrm{S} 4, \mathrm{~S} 10$ and $\mathrm{S} 11$ was better $(0.66 \mathrm{~g}, 0.61 \mathrm{~g}$ and $0.57 \mathrm{~g}$, respectively) in comparison to the top ranking seed sources and they were on par with each other however, significantly different from S1, S18 and S19 seed sources. Jahankhelan (S2), Hissar (S8), Jorhat (S15) and Farinda (S17) seed sources produced lesser seedling dry matter. 
Table 3. - Simple correlation coefficient (r) among seedling and nodulation traits of D. sissoo.

\begin{tabular}{|c|c|c|c|c|c|c|c|c|c|}
\hline Parameters & $\begin{array}{l}\text { Seedling } \\
\text { height } \\
(\mathrm{cm})\end{array}$ & $\begin{array}{c}\text { Collar } \\
\text { diameter } \\
(\mathrm{mm})\end{array}$ & $\begin{array}{l}\text { Root } \\
\text { length } \\
(\mathrm{cm})\end{array}$ & $\begin{array}{l}\text { No. of } \\
\text { green } \\
\text { nodules/ } \\
\text { seedling }\end{array}$ & $\begin{array}{c}\text { No. of } \\
\text { black } \\
\text { nodules/ } \\
\text { seedling }\end{array}$ & $\begin{array}{c}\text { Total no. } \\
\text { of } \\
\text { nodules/ } \\
\text { seedling }\end{array}$ & $\begin{array}{l}\text { Nodule } \\
\text { diameter } \\
(\mathrm{mm})\end{array}$ & $\begin{array}{l}\text { Seedling } \\
\text { fresh } \\
\text { weight }(g)\end{array}$ & $\begin{array}{l}\text { Seedling } \\
\text { dry } \\
\text { weight (g) }\end{array}$ \\
\hline $\begin{array}{l}\text { Seedling height } \\
\text { (cm) }\end{array}$ & - & $0.556 * *$ & $0.436^{*}$ & 0.302 & 0.202 & 0.304 & 0.321 & 0.651 & $0.667 * *$ \\
\hline $\begin{array}{l}\text { Collar diameter } \\
(\mathrm{mm})\end{array}$ & & - & $0.456^{*}$ & 0.336 & 0.140 & 0.296 & $0.542 * *$ & $0.684 * *$ & $0.669 * *$ \\
\hline Root length $(\mathrm{cm})$ & & & - & $0.588 * *$ & $0.540 * *$ & $0.667 * *$ & $0.505^{*}$ & $0.635^{* *}$ & $0.660 * *$ \\
\hline $\begin{array}{l}\text { No. of green } \\
\text { nodules }\end{array}$ & & & & - & $0.398^{*}$ & $0.795 * *$ & 0.350 & $0.533 * *$ & $0.544 * *$ \\
\hline $\begin{array}{l}\text { No. of black } \\
\text { nodules }\end{array}$ & & & & & - & $0.839 * *$ & 0.222 & 0.253 & 0.291 \\
\hline $\begin{array}{l}\text { Total No. of } \\
\text { nodules/plant }\end{array}$ & & & & & & - & 0.327 & $0.482 *$ & $0.502^{*}$ \\
\hline $\begin{array}{l}\text { Nodule diameter } \\
(\mathrm{mm})\end{array}$ & & & & & & & - & $0.530 * *$ & $0.462 *$ \\
\hline $\begin{array}{l}\text { Seedling fresh } \\
\text { weight }(\mathrm{g})\end{array}$ & & & & & & & & - & $0.968^{* *}$ \\
\hline $\begin{array}{l}\text { Seedling dry } \\
\text { weight (g) }\end{array}$ & & & & & & & & & - \\
\hline
\end{tabular}

** Significant at $1 \%$ level of significance.

* Significant at $5 \%$ level of significance.

\section{Correlation between characters}

Simple correlation matrix (Table 3) indicates highly significant positive correlation was observed between seedling height and collar diameter (0.556) and seedling dry weight (0.667). Collar diameter showed highly significant positive correlation with seedling fresh weight (0.684), seedling dry weight (0.669) and nodule diameter (0.542). Root length showed highly significant positive association with nodulation and seedling biomass parameters and significant positive association with seedling height and collar diameter. Number of green nodules per seedling showed highly significant positive correlation with total number of nodules per seedling (0.795) followed by root length (0.588), seedling dry weight (0.544) and seedling fresh weight (0.533). While it showed statistically non-significant association with seedling height, collar and nodule diameter. Number of black nodules per seedling showed significant positive association with only root length, number of green and total number of nodules per seedling. On the other hand, total number of nodules per seedling showed significant positive correlation with all parameters except nodule diameter, seedling height and collar diameter. Similarly, seedling dry weight showed significant positive correlation with all seedling growth and nodulation parameters except number of black nodules per seedling.

\section{Discussion}

Seedling and nodulation characters exhibited wide variation among different populations of $D$. sisso (Table 2). The observed phenotypic variation for root length, seedling biomass and nodulation traits could be genetic, because the environmental variation was kept minimum as the seedlings of all seed sources were raised in growth chamber having common water source and growing medium.
Differences observed among seed sources for nodulation pattern in this species is interesting. Of the 20 seed sources, some had very good nodulation (S19, S13, S12, S5, S4) ranging from 11 to 14 per seedling and sources such as Hissar (S6) has developed very few nodules per seedling (1.13). This indicates presence of large variation for nodulating ability seed sources. DAWsON et al. (1989) and SANGINGA et al. (1991) observed similar variation pattern in Casurina cunninghamiana and Gylricidia sepium provenances, respectively. Plant roots become infected with rhizobium when exposed and nodulation occurs on the root system. Simply inherited Mendelian genes, which preclude nodulation by either one or many strains of rhizobia, have been identified in several grain legumes (DAVIS et al., 1985). Since those genes prevent nodulation by other wise invasive rhizobia, they can be designated as resistant genes in host plants. Therefore, acceptance or rejection of rhizobium by the host plant is genetically controlled.

Some legumes show specific susceptibility to certain rhizobia, others are susceptible to their wide range, such legumes have been termed as promiscuous (KUENEMAN et al., 1984). Some plant genotypes show resistance to most rhizobial strains, but are susceptible to one or more specific strains and thus can be classified as strain specific. DAwson et al. (1989) have correlated the nodule formation with type of host species in Casurina and Allocasurina seedlings. In the present study host-endophyte specificity in nodule formation is amply demonstrated in which all seed sources grown in the same self regulated water source and sand medium, having equal chances of endophyte infection, could exhibit significant variation in nodulation among different seed sources. Rhizobial strains however, could not be identified for the lack of facilities in and around the experimental site.

Inter-correlations found among growth characters and seedling biomass in $D$. sissoo is consistent with those of 
earlier studies (SAlazAR, 1986; NGUlube, 1989). Among the growth characters, collar diameter showed highly significant positive correlation with seedling dry weight followed by plant height and root length. The significant positive correlation between total number of nodules and seedling biomass reflect that rhizobium symbiosis enhance the plant response by providing increased nitrogen for plant growth and this association indicate the importance of these traits in selection of seed sources. High correlation between root length and total number of nodules showed the influence of root length on nodulation, as the root length increases, root surface area to allow the infection from rhizobia increases.

\section{Conclusion}

The preliminary phase of this trial involving 20 seed sources revealed the existence of considerable amount of genetic variation for seedling and nodulation traits among seed sources, which provides firm base for establishment of wide range provenance trial. Although, this experiment demonstrated the presence of variation in nodulation capacities between seed sources, some more specific studies are needed in this species to determine the seed sources having high potential for nitrogen fixation. The selection therefore, should be aimed at seed source with highest level of susceptibility to root nodulation with rhizobia which could perform well in the initial stages of plantation establishment on poor sites.

\section{Acknowledgements}

The Authors are thankful to Dr. R. C. ThaPliYal, Dr. S. NAUtiYal and Dr. U. K. UniYal of Forest Research Institute, Dehradun, India and their team members for collecting and sparing the seed material.

\section{References}

Champion, H. G. and S. K. Seth (1968): The revised survey of forest types of India. New Delhi, India, 3p.

Davis, T. M., K. W. Foster and D. A. Phillips (1985): Nodulation mutants in chick pea. Crop Science 25: 345-346.

Dawson, S. O., D. G. KowALSKI and P. J. DART (1989): Variation with soil depth, topographic position and host species in the capacity of soils from an Australian locale to nodulate Casurina and Allocasurina seedlings. Plant Soil 118: 1-11.

Devagiri, G. M., R. C. Dhiman, Y. P. Singh and S. K. PATIL (2001): Seed source dependent variation in mycorrhizal colonization and nutrient uptake in Dalbergia sissoo seedlings. Journal of Tropical Forest Science 13(2): 246-257.

Kueneman, E. A., W. R. Root, K. E. Dashiell and J. HoHENBERG (1984): Breeding soybeans for the tropics capable of nodulating effectively with indigenous Rhizobium species. Plant Soil 82: 387-386.

MietTinen, P., M. Karsisto and G. M. Musa (1992): Nodulation of nine nitrogen fixing tree species grown in central Sudan. For. Ecol. Management 28: 1-6.

NGUlube, M. R. (1989): Genetic variation in seed germination and seedling growth of 20 Gliricida sepium provenances. For. Ecol. Management 28: 1-6.

PokhriYal, T. C., S. P. Chaukiyal and H. B. Naithani (1993): Nitrogen fixation and nodulation behaviour of some nitrogen fixing species from inner and outer Himalaya. Indian Forester 119: 310-319.

Sanginga, N. K., B. Marique and G. Hardenson (1991): Variation in nodulation and nitrogen fixation by Gliricidia sepium/Rhizobium spp. symbiosis in a calcareous soil. Biol. Fertil. Soils 11: 273-278.

SAlAZER, R. (1986): Genetic variation in seed and seedlings of ten provenances of Gliricidia sepium (Jacq.) Stend. For. Ecol. Management 16: 391-401.

SNEDECOR, G. W. and W. G. Cochran (Eds.). (1967): Statistical methods, VI Edn. Oxford and IBH, New Delhi, 593p.

\section{JOHN (JACK) W. DUFFIELD}

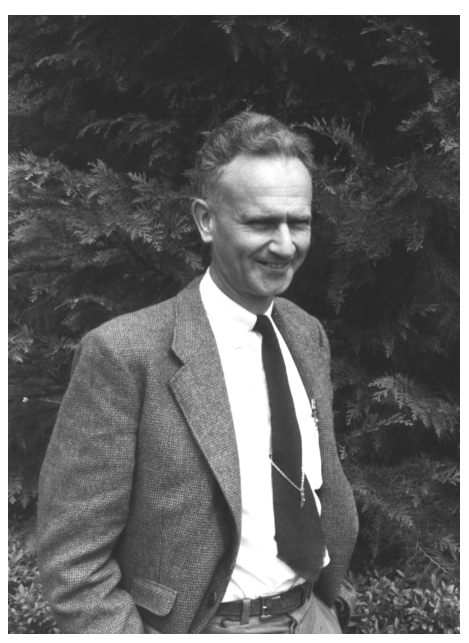

JACK DUFFIELD died July 13, 2006 in Shelton, Washington, at the age of 94 . He was an inspiration for many in forest genetics, and we regard him as one of our very best friends.

His early education was at Cornell University where he earned a B.S. in forestry and at Harvard University where he earned a Master of Forestry. He was a forester first and always and remained a member of the Society of American Foresters from 1935 until his death. He was elected a Fellow of the Society in 1960.
However, it was in forest genetics that he became a true pioneer. As early as 1940, while he was working as a forest geneticist for the USDA Forest Service's Northeastern Forest Experiment Station, he published on chromosome counts in oaks (Quercus). For the next few years, he turned out a series of papers on subjects such as pollen longevity in pines (Pinus), polyploidy in red maple (Acer rubrum), and cytological staining, published in the American Journal of Botany, the Journal of Forestry, Stain Technology, and the Journal of Heredity. One of his 1940 papers, coauthored with A. G. Snow, had the ambitious title "Genetics in Forestry", and predated classics in the field such as Bertil Lindquist's book "Genetics in Swedish Forestry Practice" by eight years and Syrach Larsen's "Genetics in Silviculture" by 18 years.

His research career was interrupted by WWII. During service with the U.S. Army in North Africa and Italy from 1942 to 1945 , JACK rose from lieutenant to major, 